\title{
Association of Low Maternal Pregnancy- associated Plasma Protein A with Adverse Perinatal Outcome
}

Panagiotis Antsaklis ${ }^{1}$, Zacharias Fasoulakis ${ }^{1}$, Marianna Theodora ${ }^{1}$, Michail Diakosavvas ${ }^{1}$, Emmanuel N. Kontomanolis ${ }^{2}$

1. Obstetrics and Gynecology, National and Kapodistrian University of Athens, Athens, GRC 2. Obstetrics and Gynecology, Democritus University of Thrace, Alexandroupolis, GRC

$\square$ Corresponding author: Zacharias Fasoulakis, hzaxos@gmail.com

Disclosures can be found in Additional Information at the end of the article

\section{Abstract}

The aim is to provide an overall view of the association of low pregnancy-associated plasma protein A (PAPP-A) levels with adverse perinatal outcomes. The available literature in PubMed/Medline regarding PAPP-A and adverse pregnancy outcomes was searched for related articles, including terms such as "PAPP-A," "intrauterine growth restriction (IUGR)," "small for gestational age (SGA)," "stillbirth," "adverse outcome," and others. The fifth percentile is supported by many recent studies to be PAPP-A's cutoff for adverse outcome detection and the increased risk seems to be extremely high below 0.2 PAPP-A MoM (multiple of the median). Apart from chromosomal abnormalities, preeclampsia, intrauterine fetal demise, and pregnancy loss have been associated with maternal serum PAPP-A. For results below the first centile, PAPP-A has a strong positive predictive value for SGA and IUGR. Except for its vital role on the cleavage of insulin-like growth factor binding proteins (IGFBP), PAPP-A has proven to be a reliable marker for prenatal screening. Even though PAPP-A as a single predictor proved to be valuable for the prediction of some adverse perinatal outcomes, in some cases, a combination of PAPP-A to other maternal serum markers led to an increase in detection rates. PAPP-A is a promising maternal serum marker for pregnancy outcome prediction with more studies needed in order for its potentials to be fully understood and exploited.

Received 05/19/2019

Review began 05/23/2019

Review ended 05/26/2019

Published 06/17/2019

CC Copyright 2019

Antsaklis et al. This is an open access article distributed under the terms of the Creative Commons Attribution License CC-BY 3.0., which permits unrestricted use, distribution, and reproduction in any medium, provided the original author and source are credited.
Categories: Obstetrics/Gynecology, Pediatrics, Preventive Medicine

Keywords: papp-a, adverse perinatal outcome, iugr, preeclampsia, stillbirth, down syndrome

\section{Introduction And Background}

The prevention and prognosis of adverse pregnancy outcomes are of great significance and, from a medical point of view, particularly challenging for the scientific community, as well as for the family and society. In addition to parental information and psychopathology, socioeconomic factors represent the main cause for creating a reliable prenatal prognostic protocol. The need for early detection and prevention of adverse perinatal outcome is necessary nowadays.

Until today, nuchal translucency and second-trimester routine ultrasound still remain the best predictors for fetal aneuploidies [1]. However, combining fetal ultrasonography to pregnancyassociated plasma protein A (PAPP-A) leads to better diagnosis and prognosis of such anomalies, making them both compulsory for first-trimester prenatal screening in developed countries. 


\section{Review}

\section{The role of PAPP-A}

PAPP-A was detected 40 years ago in the plasma of pregnant women and was immediately suspected to have several biological roles due to similarities to other carrier and modulator proteins [2]. The role of PAPP-A in pregnancy was described soon thereafter, and since then, many studies have focused on the prediction of fetal anomalies with the help of this marker.

PAPP-A is one of the two pappalysins, a protease that belongs to the superfamily of metzincin (such as astacins, adamalysins, serralysins, the matrix metalloproteinases, and the pappalysins) of metalloproteinases and participates in the local release of insulin-like growth factors. PAPPA consists of a heterotetrameric disulfide bound 2:2 complex composed of two $200 \mathrm{kDa}$ PAPP-A subunits the 206-residue proform of eosinophil major basic protein (proMBP) subunits and has been assigned to human chromosome 9q 33.1. ProMBP functions as a proteinase inhibitor of PAPP-A. During pregnancy, these two glycosylated subunits are produced separately and then united secondarily. Although the PAPP-A mRNA can be found in many tissues, the placental production exceeds any other. The syncytiotrophoblast composes the PAPP-A subunit, while proMBP is synthesized in extravillous trophoblasts, and the two subunits are combined to create the final complex at the extracellular environment [3].

The role of insulin-like growth factor-I (IGF-I) and IGF-II is regulated by binding to one of six IGF binding proteins (IGFBP). PAPP-A is a highly selective enzyme and the responsible proteinase for cleavage of IGF binding proteins (specifically, IGFBP-4, IGFBP-5, and to some extent, IGFBP-2), acting as a regulator of IGF's bioavailability. PAPP-A2, the second member of the pappalysin family, cleaves only IGFBPs 3 and 5. IGFBP is proteolyzed by PAPP-A, the bioavailability of IGF is enhanced, trophoblast invasion is mediated, and glucose and amino acids transport in the placenta is determined. PAPP-A is proven to be highly increased in blood serum of up to 100 and 10,000 times in the first and third trimesters of pregnancy, respectively, compared to the samples of nonpregnant women [4].

To date, there is no evidence of substrates, other than IGFBPs, that PAPP-A reacts with. However, except cleavaging insulin-like growth factors, several other studies about the biological role of PAPP-A have demonstrated a possible complementary role. Atherosclerosis was first to be correlated to increased PAPP-A in the 2001 study by Bayes-Genis et al. [5], and since then, several studies aimed at clarifying the connection between coronary syndrome and other atherosclerotic diseases to this metalloproteinase. Furthermore, increased levels of glomerular PAPP-A revealed an association with diabetic neuropathy, speculating a potential therapeutic role on inhibiting PAPP-A. Moreover, the involvement of PAPP-A in tumor development has been increasingly supported with an expression of PAPP-A in ovarian, breast, lung, and other cancer tissues constantly being reported [6].

\section{Prediction of adverse pregnancy outcome}

In early gestation, the placental function is believed to be mainly represented by first trimester analytes. By the 1990s, the introduction of improved biophysical monitoring techniques led many clinical studies to examine the relevance of PAPP-A to different pathological states during pregnancy and evaluating its reliability as a prognostic factor. Especially over the last two decades, the development of pioneer and affordable equipment led to wider access to available technological means. Research became more targeted and better recording led to more reliable results, and by measuring maternal serum PAPP-A levels and evaluating the results using the multiple of the median (MoM), each individual pregnant woman was able to be selected for a tighter monitoring until childbirth and to be informed on the possibilities of adverse pregnancy outcomes. 


\section{Early studies}

Cornelia De Lange Syndrome and Threatened Abortion

In 1983, Wastergaard et al. published a study of three cases reported with the Cornelia De Lange syndrome in which PAPP-A was absent from the maternal serum and trophoblastic tissue, while in the same year, abnormally low levels of PAPP-A were connected to threatened abortion in 51 patients with live fetuses by the time of sampling [7]. This result was also supported by Masson et al. in a study of 60 women presenting with vaginal bleeding in the first trimester of pregnancy [7-8].

Anembryonic Pregnancies

Other studies reported that PAPP-A could be used as a predictor for anembryonic pregnancies. In 1984, Chapman et al. reported 22 cases with normal PAPP-A levels in the eighth week, while in 1986, out of 85 pregnancies, Yovich et al. presented 16 anembryonic pregnancies with low maternal serum PAPP-A levels at the seventh week of gestation. The precondition for both studies was the normal endocrinology and histology of the placenta [9-10].

\section{Ectopic Pregnancy}

Many studies recorded low levels or even absence of first trimester serum PAPP-A during ectopic pregnancies; however, most of them supported that a combination of serum biomarkers led to safer and more reliable results [11-14]. Since serum PAPP-A concentrations are normally very low before seven weeks of gestation, when used as a single predictor, it is poorly discriminative between ectopic pregnancy and other adverse outcomes.

Pregnancy Loss

A relationship between low levels of PAPP-A and pregnancy loss has been demonstrated in many studies [15-17]. Goetzl et al. presented a study of 7,932 pregnancies where low PAPP-A results were individually associated with increased early loss (even after logistic regression analysis for maternal age and race), while normal values presented a low risk of pregnancy loss [15]. Another study on developing patient-specific risk for fetal loss was presented in 2008 by Dugoff et al. [16]. Out of 36,014 women from the First- and Second-Trimester Evaluation of Risk (FaSTER) trial, 421 had an adverse outcome, dividing the results into two groups according to the week of fetal loss ( $<24$ or $>24$ weeks). The results indicated a high detection rate with all the biomarkers examined, even though PAPP-A wasn't the only significant marker for fetal loss. In addition, Scott et al. reported in a 2009 study that when PAPP-A level is low (and even with normal karyotype), there is an increased risk of adverse outcome and fetal loss (12\% for < 0.2 PAPP-A MoM) [17]. In all studies, PAPP-A levels below the 5th centile were connected to an adverse pregnancy outcome and increased risk of fetal loss [15-17].

\section{Intrauterine fetal demise}

Intrauterine death and subsequent delivery beyond the 20th week of gestation occur in about one in 160 pregnancies in high-income countries with no improvement over the past decades. Even though major risk factors are already known for stillbirth (obesity, age, smoking, small for gestational age (SGA), diabetes, hypertension, etc.), several studies tested PAPP-A as a possible predictor for stillbirth, among other markers [18].

In 2002, Smith et al. conducted a study where the results of 8,839 pregnant women were analyzed [19]. The authors reported that women with first and early second trimester PAPP-A 
levels in the lowest 5th centile (adjusted odds ratio 3.6; 95\% CI 1.2 - 11.0) were more likely to experience intrauterine death, pointing out that the IGF system has a key role in the pregnancy outcome. The same results were reported by Dugoff et al. in 2004 [20]. Out of 34,271 pregnancies between 10 weeks, three days and 13 weeks, six days of gestation, 95 women (0.28\%) suffered intrauterine death before the 24 th week (0.02 P-value). The authors concluded (among others) that first trimester low PAPP-A levels are associated with intrauterine fetal death at $\leqslant 24$ weeks of gestation. The same results were obtained by Marleen et al. in 2014, reporting significantly lower PAPP-A levels in pregnancies resulting in intrauterine fetal death (0.25 MoM, interquartile range (IQR) 0.20 - 0.31; p 0.009) and by Kaijomaa et al. in 2017, where nine $(0.9 \%)$ stillbirths were recorded among patients with low PAPP-A levels while none were recorded in the control group [21-22].

\section{SGA - intrauterine growth restriction (IUGR)}

An important parameter that made the correlation of PAPP-A to fetal development is (the proven to be accurate) pregnancy dating that first-trimester screening ensures. However, when strictly defining growth restriction under SGA less than the 5th centile, studies usually result in a proportion of neonates with a higher risk of adverse outcomes, in contrast to studies where SGA is set below the 10th centile. Accordingly, especially when used as a single marker, PAPP-A levels < 1st centile have a strong positive predictive value (PPV) for intrauterine growth restriction (IUGR), (15.8 \% and 24\% - 26\% for SGA below the 5th and 10th centile, respectively) $[16-17,23]$.

On the contrary, reports of PAPP-A < 5th centile led many researchers to combine other indicators, even the second trimesters' markers, to increase specificity and sensitivity. Such indicators usually consist of maternal risk factors, fetal routine parameters, Doppler measurements, and monitoring the development of first trimester maternal serum markers after the 14 th week.

In 2006, Smith et al. presented a study of 8,483 women in order to associate maternal serum alpha-fetoprotein (AFP) and PAPP-A to adverse outcomes [24]. Combined, the AFP > 95th centile and PAPP-A < 5th centile levels have a $32.1 \%$ possibility for SGA, suggesting mandatory monitoring for fetal development on women with such results.

Similarly, in order to evaluate if low first-trimester serum PAPP-A can accurately predict fetal growth, Fox et al. reported a study of 239 pregnant women out of which 25 had a low PAPP-A (< 5th centile), had undergone second trimester ultrasound examination, and who had at least one second trimester marker for fetal growth restriction (estimated fetal weight $<25$ th centile, a greater than seven-day growth delay compared to the established gestational age, or a ratio of head to abdominal circumference greater than 90th centile). The authors concluded that the rate of birth weight $<10$ th centile was $47.8 \%$ and the rate of birth weight $<5$ th centile was $21.7 \%$, supporting that a poor perinatal outcome is quite possible for pregnancies with PAPP-A $<5$ th centile and with one second trimester fetal growth restriction [25].

Likewise, Cooper et al. reported in the same year a prospective interventional study in order to evaluate a possible correlation of adverse in pregnancies with low maternal serum PAPP-A level $(<0.4 \mathrm{MoM})$ and positive uterine artery Doppler (PI > 1.45) at 18 to 22 weeks of gestation [26]. Among these patients, the possibility of SGA was $36 \%$ at 18 weeks and $64 \%$ at 22 weeks [26].

\section{Preeclampsia}

Preeclampsia is a gestational disease that usually occurs during the third trimester of pregnancy. It is diagnosed clinically by maternal hypertension (> 140/90 $\mathrm{mmHg}$ ) and proteinuria (> $300 \mathrm{mg} /$ day), both mediated by angiogenic factors released into the maternal 
circulation, causing vasoconstriction due to placental dysfunction. Clinical manifestations of preeclampsia can occur during pregnancy or even after childbirth and can lead to fatal maternal and fetal complications without treatment [27].

Since PAPP-A is routinely used in first trimester screening and due to the need for an as early as possible detection of preeclampsia, most studies are conducted in the first trimester. However, some studies focused on preeclampsia prognosis using second and third trimester PAPP-A results.

\section{First Trimester}

Even though some reports concluded that PAPP-A levels of women developing preeclampsia showed no difference than the controls, many studies reported the opposite [28-30]. In 2002, the first multicenter study testing the relevance of first trimester PAPP-A to preeclampsia was published. Out of 8,839 women at eight to 14 weeks of gestation, the authors reported an increased risk of preeclampsia in the group with PAPP-A in the lowest 5 th centile (adjusted odds ratio, 2.3; 95\% CI 1.6 - 3.3) [19]. Similarly, in 2004, Dugoff et al. supported that women with PAPP-A under the 5th centile are more likely to experience preeclampsia among other adverse outcomes [28]. The same result was observed by Zwahlen et al. in 52 cases of preeclampsia and twice reported in 2009 by Poon et al. in 157 cases with decreased PAPP-A ( $0.53 \mathrm{MoM}$ and $0.93 \mathrm{MoM}$ ) and in another 156 women who developed preeclampsia with low first trimester PAPP-A levels as well (0.555 MoM and 0.911 MoM) [20, 31-33]. Many other studies have also tested the reliability of PAPP-A as a predictor for preeclampsia with positive results. Either tested as a single predictor or combined to other markers, such as placental protein-13, placental growth factor, uterine artery pulsatility index, inhibin A, and others, PAPP-A proved to be a promising predictor [34-37].

\section{Second Trimester}

Not many studies about second trimester PAPP-A levels and preeclampsia are available in the literature. First, in 2003, Bersinger et al. reported decreased levels of maternal serum PAPP-A levels in the early second trimester in 53 women (with or without fetal growth restriction) compared to 65 controls but found no difference in the late second trimester. Similarly, in 2011, D'Anna et al. supported that the best period for preeclampsia prognosis might be at the beginning of the second trimester, describing a PAPP-A level in women with preeclampsia of < 0.3 MoM. On the contrary, in 2012, Bestwick et al. concluded that the correlation of early second trimester PAPP-A and preeclampsia could be derived comparing 77 women who developed preeclampsia to 224 controls [38-40].

\section{Third Trimester}

Since 1977, increased third trimester serum PAPP-A was associated with preeclampsia. However, there are no data currently supporting that PAPP-A could be a prognostic factor for preeclampsia because some studies conducted since then support that the difference in the serum PAPP-A is observed only in women with albuminuria (severe preeclampsia); others report no differences between serum PAPP-A levels of women suffering preeclampsia and controls, while others reveal increased concentration in the third trimester [41-46].

\section{Preterm Birth}

Pregnancy disorders, such as preeclampsia and intrauterine growth restriction, are frequent reasons for preterm delivery. Therefore, most of the studies up to date have tested the reliability of PAPP-A on the prognosis of the underlying disorder rather than predicting 


\section{Cureus}

preterm delivery. To date, there are no studies proving an increased sensitivity or specificity of a single marker for early detection of preterm birth, and even though PAPP-A $<5$ th centile was reported in some cases to be possibly associated with preterm birth, no studies have currently proven a significant association of this marker with increased risk of preterm delivery (especially when using the marker MoMs as continuous variables) [16, 23].

\section{Down Syndrome}

Trisomy 21 is a maternal age-related genetic disorder that without prenatal diagnosis is estimated to be one in 800 spontaneous pregnancies. Owing to an increase in the mean age of pregnant women (one in 740 pregnancies in 1974 and one in 504 pregnancies with trisomy 21 in 1997), modern medicine led many high income-countries to provide first trimester pregnancy screening for Down syndrome [47].

In accordance with the International Prenatal Screening Research Group (IPSRG), Wald et al. presented PAPP-A as one of the two maternal serum markers with the greatest promise for trisomy 21 prediction [48]. With a median value of $0.38 \mathrm{MoM}$, PAPP-A is $60 \%$ lower in the maternal serum of pregnancies affected by Down syndrome.

With many scientists confirming this data, nowadays, screening between the 11th to 13th week of gestation has been established as one of the most financially appropriate and reliable prenatal screenings. PAPP-A combined with maternal age, nuchal translucency, and beta human chorionic gonadotropin (HCG) provides high detection rates for Down syndrome of up to $60 \%-85 \%$ for combined first trimester prenatal screening (and up to $94 \%$ with the addition of inhibin A) with only a $5 \%$ false-positive rate [1, 49-50].

\section{Combination of maternal serum markers}

In order to estimate the diagnostic value, PAPP-A's sensitivity and specificity were, among others, at the center of scientific attention being tested since the late 1970s. PAPP-A used as a single marker has proved to be of limited detection rate [33], but when combined to other markers, the sensitivity rate increases. In 2009, Akolekar et al. combined PAPP-A with inhibin A, activin A, mean arterial pressure, PP-13, soluble endoglin (sEng), pentraxin, Doppler pulsatility index (PI), placental growth factor (PIGF), and P selection, in a 33,602 patients study, resulting in $61 \%, 79 \%$, and $91 \%$ detection rates for late, intermediate, and early onset preeclampsia, respectively [29], while in 2010, Wortelboer et al. tested PAPP-A with PIGF, a disintegrin and metalloprotease 12 (ADAM 12), and disintegrin and beta hCG and reported only a $44 \%$ preeclampsia prediction rate with a 5\% false rate (Table 1) [34].

\begin{tabular}{|c|c|c|c|c|c|}
\hline $\begin{array}{l}\text { Adverse pregnancy } \\
\text { outcome }\end{array}$ & Author & Year & Participants & PAPP-A Result & $\begin{array}{l}\text { Ref. } \\
\text { No }\end{array}$ \\
\hline \multirow{4}{*}{ Ectopic pregnancy } & $\begin{array}{l}\text { Mueller et } \\
\text { al. }\end{array}$ & 2004 & 122 (43 EP) & Increased risk if $<0.02 \mathrm{MoM}$ & [11] \\
\hline & Beer et al. & 2011 & 18 (9 EP) & 20/40 significant peptides/total & [12] \\
\hline & $\begin{array}{l}\text { Rausch et } \\
\text { al. }\end{array}$ & 2011 & 200 (100 EP) & Limited diagnostic value as a single marker & [13] \\
\hline & $\begin{array}{l}\text { Daponte et } \\
\text { al. }\end{array}$ & 2005 & 50 (27 EP) & Unable to distinguish EP from alUP & [14] \\
\hline
\end{tabular}




\section{Cureus}

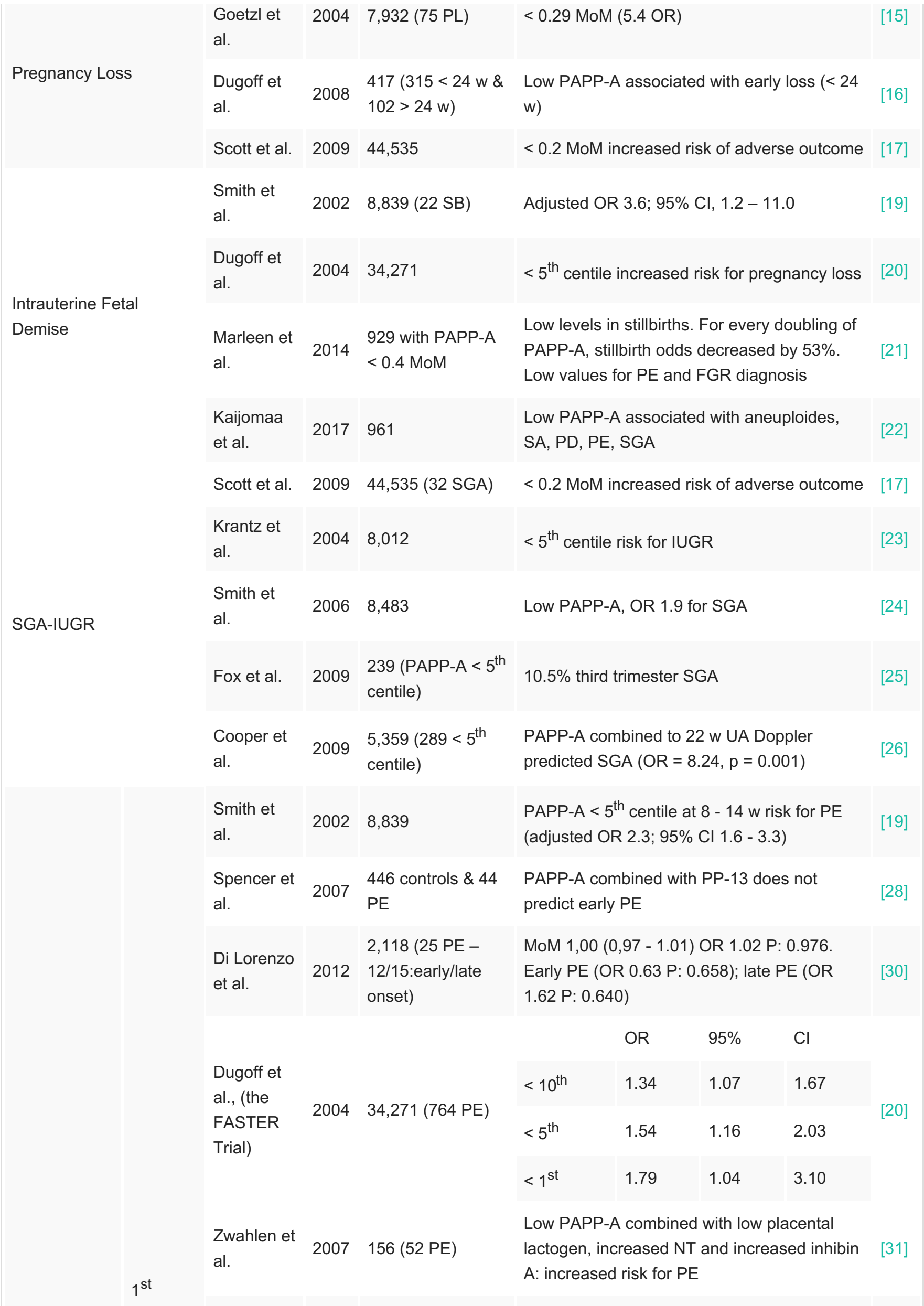




\section{Cureus}

Preeclampsia

\begin{tabular}{|c|c|c|c|}
\hline & $\begin{array}{l}\text { Nasrin et } \\
\text { al. }\end{array}$ & 2010 & 200 (3 PE) \\
\hline \multirow{3}{*}{$\begin{array}{l}2^{\text {nd }} \\
\text { trimester }\end{array}$} & $\begin{array}{l}\text { Bersinger } \\
\text { et al. }\end{array}$ & 2004 & $\begin{array}{l}118 \text { total - } 53 \text { PE } \\
\text { (28 without FGR, } \\
25 \text { with FGR }\end{array}$ \\
\hline & $\begin{array}{l}\text { D'anna et } \\
\text { al. }\end{array}$ & 2011 & 602 (40 PE) \\
\hline & $\begin{array}{l}\text { Bestwick } \\
\text { et al. }\end{array}$ & 2012 & 301 (77 PE) \\
\hline \multirow{6}{*}{$\begin{array}{l}3^{\text {rd }} \\
\text { trimester }\end{array}$} & $\begin{array}{l}\text { Muravská } \\
\text { et al. }\end{array}$ & 2011 & 279 (35 PE) \\
\hline & Lin et al. & 1977 & $\begin{array}{l}88 \text { (32 with } \\
\text { toxemia - diastolic } \\
\text { blood pressure } \\
\text { greater than } 110 \text { ) }\end{array}$ \\
\hline & $\begin{array}{l}\text { Hughes et } \\
\text { al. }\end{array}$ & 1980 & 272 (39 PE) \\
\hline & $\begin{array}{l}\text { Imaizumi } \\
\text { et al. }\end{array}$ & 1983 & $\begin{array}{l}231 \text { (44 } \\
\text { pathological) }\end{array}$ \\
\hline & $\begin{array}{l}\text { Barnea et } \\
\text { al. }\end{array}$ & 1986 & $\begin{array}{l}49(13 \\
\text { hypertension - } \\
\text { toxemia) }\end{array}$ \\
\hline & Atis et al. & 2012 & 73 (36 PE) \\
\hline
\end{tabular}

Poon et al.

(A)

Poon et al.

(B)

Wortelboer

et al.

Audibert et

al.

2010893 (40 PE)

Kang et al. $2008 \quad 3076$ (32 PE)

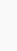

Atis et al.

$200934 \mathrm{w}$ and 124
2009 7,797 (34 PE)

Early and late PE combined to decreased

PAPP-A (0.53 MoM and 0.93 MoM)

156 (32 delivery $<\quad<5^{\text {th }}$ centile in $21.9 \%$ of early and $6.5 \%$ of

delivery $>34 \mathrm{w}$ )

late PE and association between log UtA-PI

MoM and log PAPP-A MoM $(P=0.001)$

Low PAPP-A (median 0.82 MoM, $\mathrm{P}<0.02$ )

PAPP-A combined with clinical

characteristics, inhibin A and PGF $=75 \%$

detection of early-onset $\mathrm{PE}$

$1^{\text {st }}$ trimester PAPP-A concentration was

significantly lower and concentrations of early

$2^{\text {nd }}$ trimester inhibin-A and hCG significantly elevated

PAPP-A sensitivity: $82 \%$, specificity: $95 \%$,

PPV: $87 \%$, NPV: 93\%

PAPP-A reduced at $23 \& 35 \mathrm{w}$ of gestations with subsequent $P E$

Possible detection of PE at $14-17$ w

No use for early detection of 2nd trimester PE ( 0.97 MoM (95\% confidence interval 0.73 to 1.25))

Increased PAPP-A compared to controls $(\mathrm{p}<$ $0.05)$ - association of TT genotype of Cys327Cys polymorphism of the PAPP-

A gene with preeclampsia

Elevated PAPP-A in women with toxemia

Elevated PAPP-A in PE patients

Elevated PAPP-A in PE patients

A higher placental concentration of PAPP-A in patients with hypertension than those with toxemia

PAPP-A level at last trimester increases in all mild-severe PE but not predictive for the 


\section{Cureus}

\section{TABLE 1: Studies on PAPP-A and Adverse Pregnancy Outcomes}

alUP: abnormal intrauterine pregnancy; CI: confidence interval; EP: ectopic pregnancy; FASTER: First- and Second-Trimester Evaluation of Risk trial; FGR: fetal growth restriction; hCG: human chorionic gonadotropin; IUGR: intrauterine growth restriction; MoM: multiple of the median: NPV: negative predictive value; NT:nuchal translucency; OR: odds ratio; PAPP-A: pregnancy-associated plasma protein A; PD: preterm delivery; PE: preeclampsia; PGF: placental growth factor; PL: pregnancy loss; PP-13: placental protein-13; PPV: positive predictive value; SA: spontaneous abortion; SB: stillbirth; SGA: small for gestational age; UA Doppler: uterine artery Doppler; UtA-PI: uterine artery pulsatility index; w: weeks

\section{Conclusions}

To date, the established association of low PAPP-A levels to Down syndrome has led to the wide use of PAPP-A measurement for the diagnosis and prognosis of prenatal adverse outcomes. Over the last decades, low maternal serum PAPP-A at 11 to 13 weeks of gestation has been tested with promising results as a prognostic factor for many adverse pregnancy outcomes. In particular, PAPP-A has shown great promise in the diagnosis and prognosis of Down syndrome, stillbirth, SGA, IUGR, and preeclampsia. Due to its particular features, ease of measurement and the variety of studies testing it, PAPP-A has become an integral part of prenatal control with data proving that this marker can be used either as a single predictor or combined with other maternal serum markers. So far, PAPP-A, beta HCG, maternal age, and nuchal translucency quantification are used as a mandatory protocol for prenatal screening in many high-income countries. In addition, the cut-off percentiles and multiple of the media are indicators of the pregnancy risks so that therapists are better able to provide a more careful morphological assessment, followed by stricter monitoring of fetal growth, and in order to inform and guide pregnant women on the possible pregnancy outcomes. PAPP-A has been an innovation in the last decade for prenatal screening; however, more studies are needed in order to achieve the best predicting values for specific structural abnormalities and genetic syndromes.

\section{Additional Information \\ Disclosures}

Conflicts of interest: In compliance with the ICMJE uniform disclosure form, all authors declare the following: Payment/services info: All authors have declared that no financial support was received from any organization for the submitted work. Financial relationships: All authors have declared that they have no financial relationships at present or within the previous three years with any organizations that might have an interest in the submitted work. Other relationships: All authors have declared that there are no other relationships or activities that could appear to have influenced the submitted work.

\section{References}

1. Nicolaides KH: Screening for fetal aneuploidies at 11 to 13 weeks . Prenat Diagn. 2011, 31:7-15. 10.1002/pd.2637

2. Lin TM, Halbert SP, Spellacy WN: Measurement of pregnancy-associated plasma proteins during human gestation. J Clin Invest. 1974, 54:576-82. 10.1172/JCI107794

3. Sinosich MJ: Molecular characterization of pregnancy-associated plasma protein-A by electrophoresis. Electrophoresis. 1990, 11:70-78. 10.1002/elps.1150110115

4. Monget P, Mazerbourg S, Delpuech T, et al.: Pregnancy-associated plasma protein-A is involved in insulin-like growth factor binding protein-2 (IGFBP-2) proteolytic degradation in bovine and porcine preovulatory follicles: identification of cleavage site and characterization 
of IGFBP-2 degradation. Biol Reprod. 2003, 68:77-86. 10.1095/biolreprod.102.007609

5. Bayes-Genis A, Conover CA, Overgaard MT, et al.: Pregnancy-associated plasma protein A as a marker of acute coronary syndromes. N Engl J Med. 2001, 345:1022-29.

10.1056/NEJMoa003147

6. Mader JR, Resch ZT, McLean GR, Mikkelsen JH, Oxvig C, Marler RJ, Conover CA: Mice deficient in PAPP-A show resistance to the development of diabetic nephropathy. J

Endocrinol. 2013, 219:51-58. 10.1530/JOE-13-0167

7. Westergaard JG, Sinosich MJ, Bugge M, Madsen LT, Teisner B, Grudzinskas JG: Pregnancyassociated plasma protein A in the prediction of early pregnancy failure. Am J Obstet Gynecol. 1983, 145:67-69. 10.1016/0002-9378(83)90341-1

8. Westergaard JG, Chemnitz J, Teisner B, Poulsen HK, Ipsen L, Beck B, Grudzinskas JG: Pregnancy-associated plasma protein A: a possible marker in the classification and prenatal diagnosis of Cornelia de Lange syndrome. Prenat Diagn. 1983, 3:225-32.

10.1002/pd.1970030307

9. Yovich JL, Willcox DL, Grudzinskas JG, Bolton AE: The prognostic value of HCG, PAPP-A, oestradiol-17 beta and progesterone in early human pregnancy. Aust N Z J Obstet Gynaecol. 1986, 26:59-64. 10.1111/j.1479-828X.1986.tb01530.x

10. Stabile I: Anembryonic Pregnancy. The Embryo. Chapman MG, Grudzinskas JG, Chard T (ed): Springer, London; 1991. 35-43. 10.1007/978-1-4471-1802-2_3

11. Mueller MD, Raio L, Spoerri S, Ghezzi F, Dreher E, Bersinger NA.: Novel placental and nonplacental serum markers in ectopic versus normal intrauterine pregnancy. Fertil Steril. 2004, 81:1106-11. 10.1016/j.fertnstert.2003.08.049

12. Beer LA, Tang HY, Sriswasdi S, Barnhart KT, Speicher DW: Systematic discovery of ectopic pregnancy serum biomarkers using 3-D protein profiling coupled with label-free quantitation. J Proteome Res. 2011, 10:1126-38. 10.1021/pr1008866

13. Rausch ME, Sammel MD, Takacs P, Chung K, Shaunik A, Barnhart KT: Development of a multiple marker test for ectopic pregnancy. Obstet Gynecol. 2011, 117:573-82.

10.1097/AOG.0b013e31820b3c61

14. Daponte A, Pournaras S, Zintzaras E, Kallitsaris A, Lialios G, Maniatis AN, Messinis IE: The value of a single combined measurement of VEGF, glycodelin, progesterone, PAPP-A, HPL and LIF for differentiating between ectopic and abnormal intrauterine pregnancy. Hum Reprod. 2005, 20:3163-66. 10.1093/humrep/dei218

15. Goetzl L, Krantz D, Simpson JL, et al.: Pregnancy-associated plasma protein A, free beta-hCG, nuchal translucency, and risk of pregnancy loss. Obstet Gynecol. 2004, 104:30-36.

10.1097/01.AOG.0000129969.78308.4f

16. Dugoff L, Cuckle HS, Hobbins JC, et al.: Prediction of patient-specific risk for fetal loss using maternal characteristics and first- and second-trimester maternal serum Down syndrome markers. Am J Obstet Gynecol. 2008, 199:290.e1-6. 10.1016/j.ajog.2008.06.099

17. Scott F, Coates A, McLennan A: Pregnancy outcome in the setting of extremely low first trimester PAPP-A levels. Aust N Z J Obstet Gynaecol. 2009, 49:258-62. 10.1111/j.1479828X.2009.01001.X

18. Flenady V, Koopmans L, Middleton P, et al.: Major risk factors for stillbirth in high-income countries: a systematic review and meta-analysis. Lancet. 2011, 377:1331-40. 10.1016/S01406736(10)62233-7

19. Smith GCS, Stenhouse EJ, Crossley JA, Aitken DA, Cameron AD, Connor JM: Early pregnancy levels of pregnancy-associated plasma protein A and the risk of intrauterine growth restriction, premature birth, preeclampsia, and stillbirth. J Clin Endocrinol Metab. 2002, 87:1762-67. 10.1210/jcem.87.4.8430

20. Dugoff L, Hobbins JC, Malone FD, et al.: First-trimester maternal serum PAPP-A and free-beta subunit human chorionic gonadotropin concentrations and nuchal translucency are associated with obstetric complications: A population-based screening study (The FASTER Trial). Am J Obstet Gynecol. 2004, 191:1446-51. 10.1016/j.ajog.2004.06.052

21. Marleen FS, Shahid I, Hashi AA, Rebecca A, Aquilina J: P14.29: First trimester low pregnancyassociated plasma protein-A (PAPP-A) levels and uteroplacental complications: a retrospective cohort study. Ultrasound Obstet Gynecol. 2014, 44:269. 10.1002/uog.14283

22. Kaijomaa M, Rahkonen L, Ulander VM, et al.: Low maternal pregnancy-associated plasma protein A during the first trimester of pregnancy and pregnancy outcomes. Int J Gynaecol Obstet. 2017, 136:76-82. 10.1002/ijgo.12002 
23. Krantz D, Goetzl L, Simpson JL, et al.: Association of extreme first-trimester free human chorionic gonadotropin-beta, pregnancy-associated plasma protein A, and nuchal translucency with intrauterine growth restriction and other adverse pregnancy outcomes. Am J Obstet Gynecol. 2004, 191:1452-58. 10.1016/j.ajog.2004.05.068

24. Smith GCS, Shah I, Crossley JA, et al.: Pregnancy-associated plasma protein A and alphafetoprotein and prediction of adverse perinatal outcome. Obstet Gynecol. 2006, 107:161-66. 10.1097/01.AOG.0000191302.79560.d8

25. Fox NS, Shalom D, Chasen ST: Second-trimester fetal growth as a predictor of poor obstetric and neonatal outcome in patients with low first-trimester serum pregnancy-associated plasma protein-A and a euploid fetus. Ultrasound Obstet Gynecol. 2009, 33:34-38. 10.1002/uog.6274

26. Cooper S, Johnson JA, Metcalfe A, et al.: The predictive value of 18 and 22 week uterine artery Doppler in patients with low first trimester maternal serum PAPP-A. Prenat Diagn. 2009, 29:248-52. 10.1002/pd.2175

27. Sircar M, Thadhani R, Karumanchi SA: Pathogenesis of preeclampsia. Curr Opin Nephrol Hypertens. 2015, 24:131-38. 10.1097/MNH.0000000000000105

28. Spencer K, Cowans NJ, Chefetz I, Tal J, Meiri H: First-trimester maternal serum PP-13, PAPPA and second-trimester uterine artery Doppler pulsatility index as markers of pre-eclampsia. Ultrasound Obstet Gynecol. 2007, 29:128-34. 10.1002/uog.3876

29. Akolekar R, Syngelaki A, Beta J, Kocylowski R, Nicolaides KH: Maternal serum placental protein 13 at 11-13 weeks of gestation in preeclampsia. Prenat Diagn. 2009, 29:1103-108. 10.1002/pd.2375

30. Di Lorenzo G, Ceccarello M, Cecotti V, et al.: First trimester maternal serum PIGF, free $\beta$-hCG, PAPP-A, PP-13, uterine artery Doppler and maternal history for the prediction of preeclampsia. Placenta. 2012, 33:495-501. 10.1016/j.placenta.2012.03.003

31. Zwahlen M, Gerber S, Bersinger NA: First trimester markers for pre-eclampsia: placental vs. non-placental protein serum levels. Gynecol Obstet Invest. 2007, 63:15-21. 10.1159/000094672

32. Poon LC, Kametas NA, Maiz N, Akolekar R, Nicolaides KH: First-trimester prediction of hypertensive disorders in pregnancy. Hypertension. 2009, 53:812-18.

10.1161/HYPERTENSIONAHA.108.127977

33. Poon LCY, Maiz N, Valencia C, Plasencia W, Nicolaides KH: First-trimester maternal serum pregnancy-associated plasma protein-A and pre-eclampsia. Ultrasound Obstet Gynecol. 2009, 33:23-33. 10.1002/uog.6280

34. Wortelboer EJ, Koster MPH, Cuckle HS, Stoutenbeek PH, Schielen PC, Visser GH: Firsttrimester placental protein 13 and placental growth factor: markers for identification of women destined to develop early-onset pre-eclampsia. BJOG. 2010, 117:1384-89.

10.1111/j.1471-0528.2010.02690.x

35. Audibert F, Boucoiran I, An N, Aleksandrov N, Delvin E, Bujold E, Rey E: Screening for preeclampsia using first-trimester serum markers and uterine artery Doppler in nulliparous women. Am J Obstet Gynecol. 2010, 203:383.e1-8. 10.1016/j.ajog.2010.06.014

36. Kang JH, Farina A, Park JH, et al.: Down syndrome biochemical markers and screening for preeclampsia at first and second trimester: correlation with the week of onset and the severity. Prenat Diagn. 2008, 28:704-709. 10.1002/pd.1997

37. Nasrin B, Fatema N, Jebunnessa F, Shamim S, Chowdhury SB, Ali L: Early pregnancy maternal serum PAPP-A and urinary protein-creatinine ratio as predictive markers of pregnancy induced hypertension. Mymensingh Med J. 2010, 19:267-74.

38. Bersinger NA, Ødegård RA: Second- and third-trimester serum levels of placental proteins in preeclampsia and small-for-gestational age pregnancies. Acta Obstet Gynecol Scand. 2004, 83:37-45. 10.1111/j.1600-0412.2004.00277.x

39. D’Anna R, Baviera G, Giordano D, Russo S, Santamaria A, Granese R, Corrado F: ADAM 12 and PAPP-A at 14-17 weeks' gestation as biomarkers of pre-eclampsia. Prenat Diagn. 2011, 31:602-604. 10.1002/pd.2737

40. Bestwick JP, George LM, Wu T, Morris JK, Wald NJ: The value of early second trimester PAPPA and ADAM12 in screening for pre-eclampsia. J Med Screen. 2012, 19:51-54. 10.1258/jms.2012.011085

41. Muravská A, Germanová A, Jáchymová M, Hájek Z, Svarcová J, Zima T, Kalousová M: Association of pregnancy-associated plasma protein A polymorphism with preeclampsia - A 
pilot study. Clin Biochem. 2011, 44:1380-84. 10.1016/j.clinbiochem.2011.09.015

42. Lin TM, Halbert SP, Spellacy WN, Berne BH: Plasma concentrations of four pregnancy proteins in complications of pregnancy. Am J Obstet Gynecol. 1977, 128:808-10. 10.1016/00029378(77)90725-6

43. Hughes G, Bischof P, Wilson G, Smith R, Klopper A: Tests of fetal wellbeing in the third trimester of pregnancy. Br J Obstet Gynaecol. 1980, 87:650-56. 10.1111/j.1471-

0528.1980.tb04596.x

44. Imaizumi H: Fluctuations in pregnancy-associated protein A (PAPP-A) levels in the sera of pregnant women (Article in Japanese). Nihon Sanka Fujinka Gakkai Zasshi. 1983, 35:159-67.

45. Barnea ER, Bischoff P, Page C, DeCherney AH, Herrmann W, Naftolin F: Placental and circulating pregnancy-associated plasma protein A concentrates in normal and pathological term pregnancies. Obstet Gynecol. 1986, 68:382-86. 10.1097/00006250-198609000-00019

46. Atis A, Aydin Y, Basol E, Kaleli S, Turgay F, Goker N: PAPP-A levels of late pregnancy in preeclampsia and HELLP syndrome. Arch Gynecol Obstet. 2012, 285:45-49. 10.1007/s00404011-1912-z

47. Egan JFX, Benn P, Borgida AF, Rodis JF, Campbell WA, Vintzileos AM: Efficacy of screening for fetal down syndrome in the United States from 1974 to 1997. Obstet Gynecol. 2000, 96:979-85. 10.1016/S0029-7844(00)01044-9

48. Wald NJ, Kennard A, Hackshaw A, McGuire A: Antenatal screening for Down's syndrome. J Med Screen. 1997, 4:181-246. 10.1177/096914139700400402

49. Cuckle H, Benn P, Wright D: Down syndrome screening in the first and/or second trimester: model predicted performance using meta-analysis parameters. Semin Perinatol. 2005, 29:25257. 10.1053/j.semperi.2005.05.004

50. Nicolaides KH, Spencer K, Avgidou K, Faiola S, Falcon O: Multitcenter study of first-trimester screening for trisomy 21 in 75,821 pregnancies: results and estimation of the potential impact of indidivual risk-orientated two-stage first-trimester screening. Ultrasound Obs Gynecol. 2005, 25:221-26. 10.1002/uog.1860 